\title{
The cultural landscape of the Linares-La Carolina mining district (Spain)
}

\section{Kulturowy krajobraz rejonu górniczego Linares-La Carolina (Hiszpania)}

Antonio Angel Peréz Sánchez ${ }^{1}$, Marek W. Lorenc ${ }^{2}$

${ }^{1}$ Colectivo Proyecto Arrayanes, Plaza Ayuntamiento s/n (bajos parking), 23700 Linares (Jaén), Spain.

${ }^{2}$ Institute of Landscape Architecture, Wroctaw University of Environmental and Life Sciences, pl. Grunwaldzki 24a, 50-363 Wroctaw, Poland

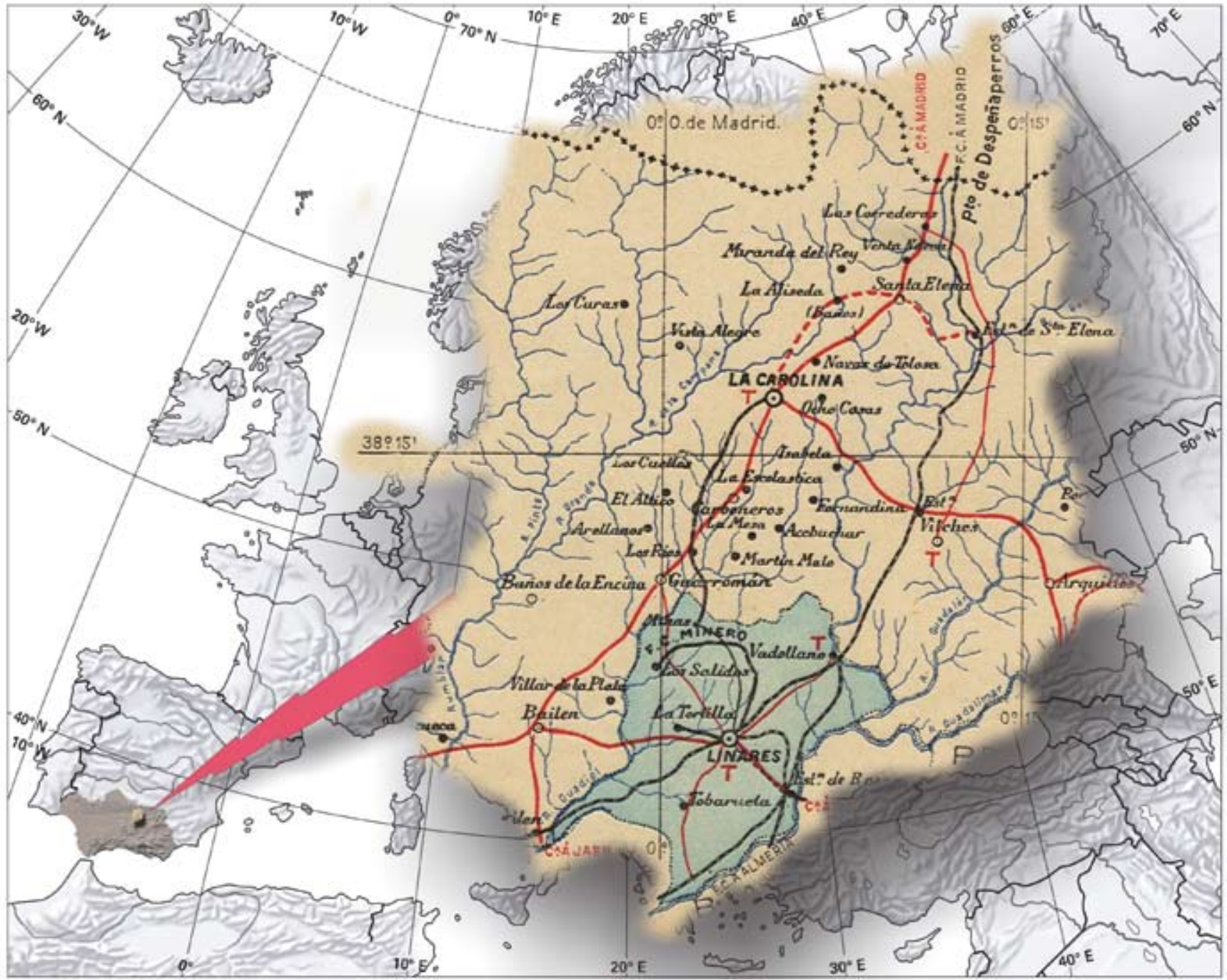

Fig. 1. Situation map of the Linares-La Carolina mining district (Fig 1-14: from the Graphic Archive of the Colectivo Proyecto Arrayanes) - Szkic sytuacyjny rejonu górniczego Linares-La Carolina (Fig 1-14: ze zbiorów archiwalnych Colectivo Proyecto Arrayanes)

\begin{abstract}
The Linares-La Carolina mining district is located in the north of Andalusia. In 1999, the European partners of the MINET (European Mining Heritage Network) Project visited the district and described it as "The best kept secret in Europe". This is a heritage of international historical, technological, cultural and economic importance with an exceptional concentration of remains. Some of these, unmatched anywhere, represent 4000 years of mining history, and of an intense "Industrial Revolution" that shaped a unique cultural landscape.

The great importance of the mining and smelting activities in the area during the industrial period resulted in numerous different buildings that changed the aspect of the place and left their mark in towns and villages, creating a distinctive landscape. The ore dressing floors,
\end{abstract}

significant features in themselves, gave rise to huge waste accumulations, tailings and dams that deeply mark the landscape.

The first Cornish pumping engine was installed in Pozo Ancho Mine in 1849, proving to be such a success that a great proportion of the area's mines were equipped with these Leviathans of the industrial world. There are still a great number of Cornish pumping Engine Houses in the district. Their robust construction has allowed them to continue to stand out as reference points in the landscape and as symbols of industrial architecture. The Linares-La Carolina District has probably one of the largest concentrations of pumping engine houses in the world.

Six important foundries (La Cruz, Arroyo Hidalgo, La Esperanza, La Tortilla, La Fortuna and San Luis) were working at the same 
The cultural landscape of the Linares-La Carolina mining district (Spain)

time in Linares, and three more in La Carolina. In these, galena was smelted to produce metallic lead.

The ancient mining routes, and the revaluation of an Iberian-Roman settlement, are foci for several archaeological investigations currently being carried out in the area. These have confirmed the antiquity of the mining and smelting. These could be included as part of the tourist experience. A reconstruction of the IberianRoman settlement, including a small village and a mine, could be a key element illustrating how this area developed at the start of its mining history. Currently, several projects are turning the mining heritage into a real resource for social regeneration and as an attraction for visitors.

The landscape of the Linares-La Carolina mining district should be a real museum that people would wish to visit. There is a need to preserve and interpret both artifacts and a way of life. The Arrayanes Project has been, and must be in the future, a partnership between the local people and their heritage.

A long term aim is to get the Mining Landscape of the the Linares-La Carolina district designated as a UNESCO World Heritage Site.

Treść: Rejon górniczy Linares-La Carolina leży w pótnocnej Andaluzji. W 1999 r. partnerzy europejskiego projektu MINET (European Mining Heritage Network), stanowiqcego zalażek późniejszej Europejskiej Sieci Dziedzictwa Górniczego 'EUROPAMINES', odwiedzili ten rejon i określili go jako „Najlepiej trzymana tajemnice w Europie”. Jest to dziedzictwo o międzynarodowym znaczeniu historycznym, technologicznym, kulturowymi iekonomicznym, będqce szczególnym nagromadzeniem tego typu zabytków. Niektóre z nich, niespotykane nigdzie indziej, przedstawiaja 4000 lat historii górnictwa i nasilonej „, Rewolucji Przemystowej”, która uksztaltowała unikalny krajobraz kulturowy tej części Hiszpanii.

Wielkie znaczenie działalności górniczej i hutniczej na tym obszarze, w okresie przemystowym skutkowato powstaniem wielu rozmaitych budowli, które zmienity aspekt tego miejsca $i$ pozostawity swoje znamie $w$ miastach $i$ wsiach, tworzac charakterystyczny krajobraz. Zakłady przetwórcze rudy, bardzo charakterystyczne same $w$ sobie, daty poczatek gromadzeniu się wielkiej ilości odpadów, hatd dobitnie znaczacych tutejszy krajobraz.

Pierwszy parowy silnik maszyny odwadniajacej, pochodzacy z Kornwalii, zostat z sukcesem zainstalowany w szybie Pozo Ancho w 1849 r. Niebawem znaczna część kopalni na tym terenie została wyposażona w podobnego typu ,olbrzymy” świata przemysłowego. Do chwili obecnej na tym obszarze istnieje wiele maszynowni typu kornwalijskiego, zarówno pompowych jak i wyciagowych. Ich mocna konstrukcja pozwoliła przetrwać jako punkty odniesienia $w$ krajobrazie i jako symbole architektury przemystowej. Rejon Linares-La Carolina reprezentuje przypuszczalnie największe zageszczenie maszynowni tego rodzaju na świecie.

Równocześnie funkcjonowato w Linares sześć hut (La Cruz, Arroyo Hidalgo, La Esperanza, La Tortilla, La Fortuna i San Luis) oraz dwie w La Carolina. W nich z galeny wytapiano metaliczny ołów.

Dawne szlaki górnicze oraz pozostałości osadnictwa iberorzymskiego sq miejscami aktualnie prowadzonych wnikliwych badań archeologicznych. Właśnie one potwierdzity wiekowość tutejszego górnictwa i hutnictwa. Stanowiska archeologiczne zostana wtaczone do kompleksowej oferty turystycznej. Rekonstrukcja dawnego osadnictwa, z drobnymi wioskami $i$ kopalniami włacznie, może być ważnym elementem ukazujacym, jak obszar ten rozwijat się u poczq̨tków swojej górniczej historii. Obecnie, wiele projektów badawczych przywraca dziedzictwo górnicze do właściwych zasobów wartości spotecznej i jako atrakcje dla odwiedzajacych.

Caty rozlegty obszar górniczy Linares-La Carolina powinien stać się otwartym muzeum, które społeczeństwo chciałoby odwiedzać. Długoterminowym projektem jest rozpoczęcie procedury zgłoszenia Krajobrazu Górniczego rejonu Linares-La Carolina na listę Stanowisk Światowego Dziedzictwa UNESCO.

\section{Linares-La Carolina mining district}

The Linares-La Carolina mining district in the north of the Province of Jaén, in the region of Andalusia, extends about 40 kilometers to the south from Despeńaperros (in Sierra Morena) and about 30 kilometers from east to west (Fig. 1). In 1999, the European partners of the MINET (European Mining Heritage Network) Project visited the district. Some of the visitors published an article in a local Cornish newspaper describing the huge importance of what they had seen. This appreciation of our heritage confirmed our own views based on work carried out from 1991 when the Arrayanes Project was launched. This is a heritage of international historical, technological, cultural and economic importance with an exceptional concentration of remains, some unmatched elsewhere and representing of an intense "Industrial Revolution". Four thousand years of mining history have shaped a unique landscape that shows how humans have related with their environment since the Bronze Age when the Argarica Culture came from the south west looking for copper and established several large settlements along the beds of the rivers that flow from the Sierra Morena (Contreras, 2000). The settlement of Peńalosa, recently studied by archaeologists from the University of Granada, was the focal point of

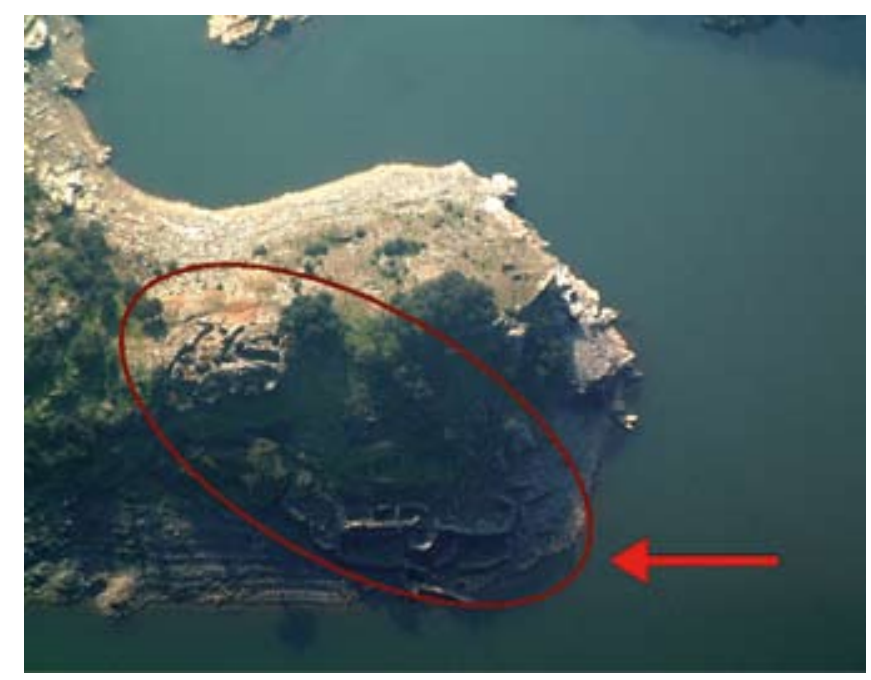

Fig. 2. Settlement from the Bronze Age at Peñalosa (Baños de La Encina) • Osada z Epoki Brązu w Peñalosa (Baños de La Encina)

a systematic colonization of all the Rumblar area. The association Arrayanes Project has identified several mines exploited for copper in that period (Fig. 2).

Later, Romans and Carthaginians sought the cooperation of the Iberian people to exploit their rich copper and lead 


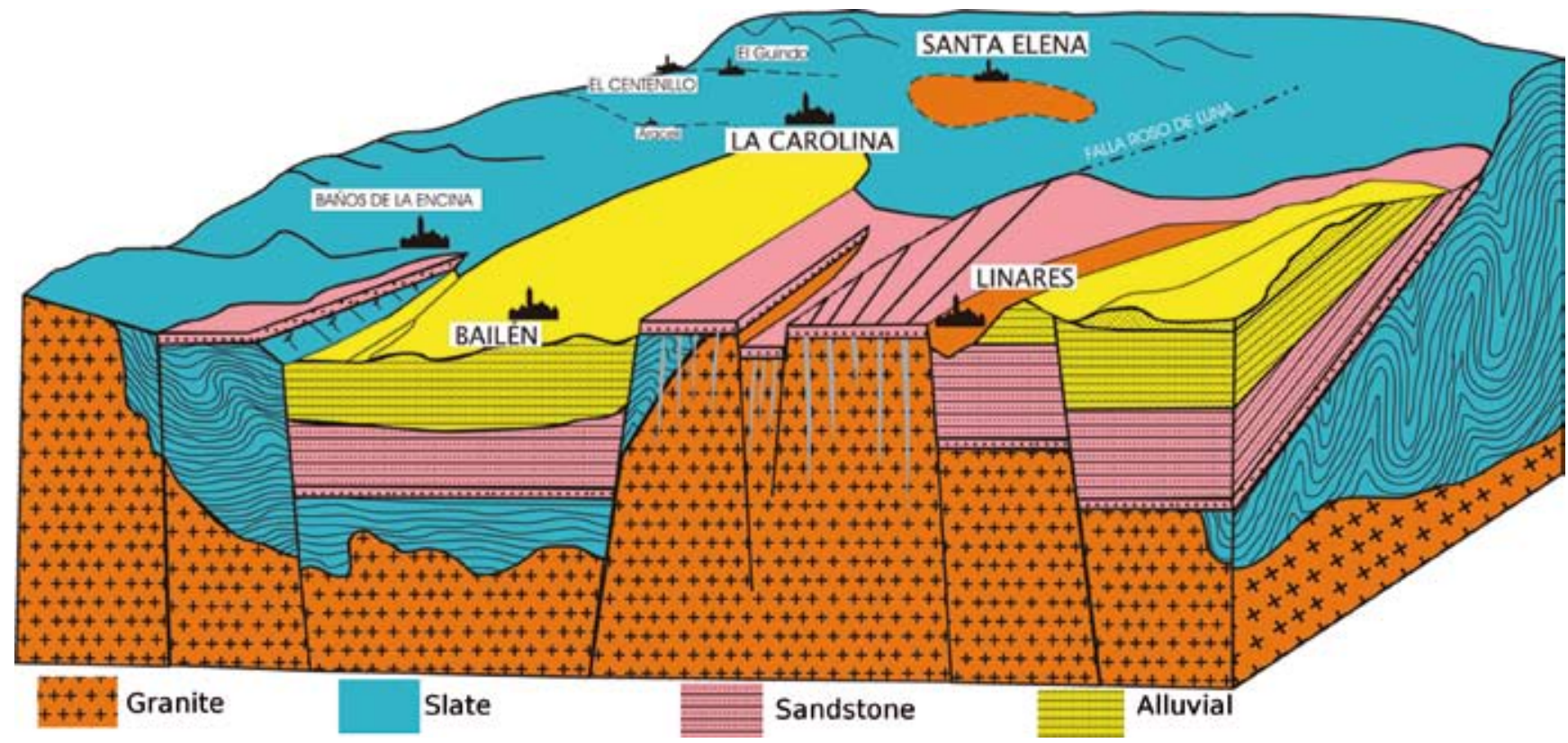

Fig. 3. Scheme of geological structure of the area Linares - La Carolina (after Azcárate, 1977, modified) • Schemat budowy geologicznej rejonu Linares-La Karolina (wg Azcárate, 1977, zmodyfikowany).

deposits. The Romans established several mines near Linares (including Arrayanes and La Cruz) and in the Sierra Morena (El Centenillo and Salas de Galiarda), where mining and metallurgical activity assumed great importance as is testified by associated defensive fortifications. The Romans applied cutting edge technology to the mines; well preserved Roman waterwheels and Archimedes screws were discovered at El Centenillo in 1911 (Arboledas, 2007).

The Iberian town of Cástulo, near Linares, was the capital of the mining district during the Roman period. Registries dating from 1563 , referring to mining concessions in the area, point to continued mineral exploitation in the Middle Ages and the period of Moorish domination. In 1749, the Spanish Crown took an interest in the district, choosing to work the Arrayanes Mine. Mining assumed a new and important impetus, which attracted many technicians and specialized workers from the Almaden Mines.

\section{The geology of the mining district}

The district is divided in two areas with different geological and morphological characteristics (Fig. 3). The southeast area includes part of the municipalities of Bailén, Linares, Vilches and Guarromán, with a mixed landscape of countryside and the foothills of Sierra Morena (Fig. 4). The surface of the country here is a successive undulation of hills and valleys. These valleys are clearly product of erosion process.

The metal-bearings rock of this area is compact granite, slightly micaceous, which distinctive component is feldspar. Capping the granite is ferruginous quartzose sandstone, sometimes resting directly upon it, at other places upon a stratum of clay, which intervenes between it and the granite. The thickness of the sandstone deposit is very variable, as well as the stratum of clay. The metalliferous fissures traverse to the granite and the sandstone, which would indicate that they were posterior to the deposition of the more recent strata. The formation of this geological structure can be summarized in three stages. After a first stage of extension and a second stage of local compression, that gave raise to several faults, the third stage of opening, during which occurred the filler of the veins, was of widespread magmatic activity, developing hydrothermal systems that gave raise to the mineralization. The main veins supplies in granite, with regular and clean fissures (Thomas, 1857).

The northwest area of the district includes part of the municipalities of Bańos de la Encina, Carboneros, La Carolina and Santa Elena (Fig. 5). In it appear Paleozoic materials, rocks affected by a regional metamorphism medium or low, which come together in three groups. The lower one, made up for old materials as quartzite and phyllite, the intermediate one composed of argillaceous slate, known as "sliding slate", and, finally, the third one with limestone and slate (Itinerario minero..., 2000). The argillaceous slate overlying the granite, at the contact zone is penetrated by numerous granitic veins. This slate is also capped with sandstone in the same way as the neighboring granite, and near the contact is transformed into metamorphic rock, resembling very fine grained granite. The metalliferous veins transverse both the granite and the slate. The original lodes field origin is the same that in Linares area, with veins in four different directions (Thomas, 1857).

Among the general characteristics of the lodes of the district may be mentioned the following, though they are by no means unexceptional ones: a north-easterly bearing, in most cases varying between $40^{\circ}$ and $70^{\circ}$; a decided tendency in the most powerful lodes to vary from northerly bearing than those of not so champion a character; a north-westerly underlie in most clear varying very little from the perpendicular, and, where such variation is greatest, a tendency to bunchiness in the lode. The back of the most productive lodes are generally composed by decomposed granite, traversed by 


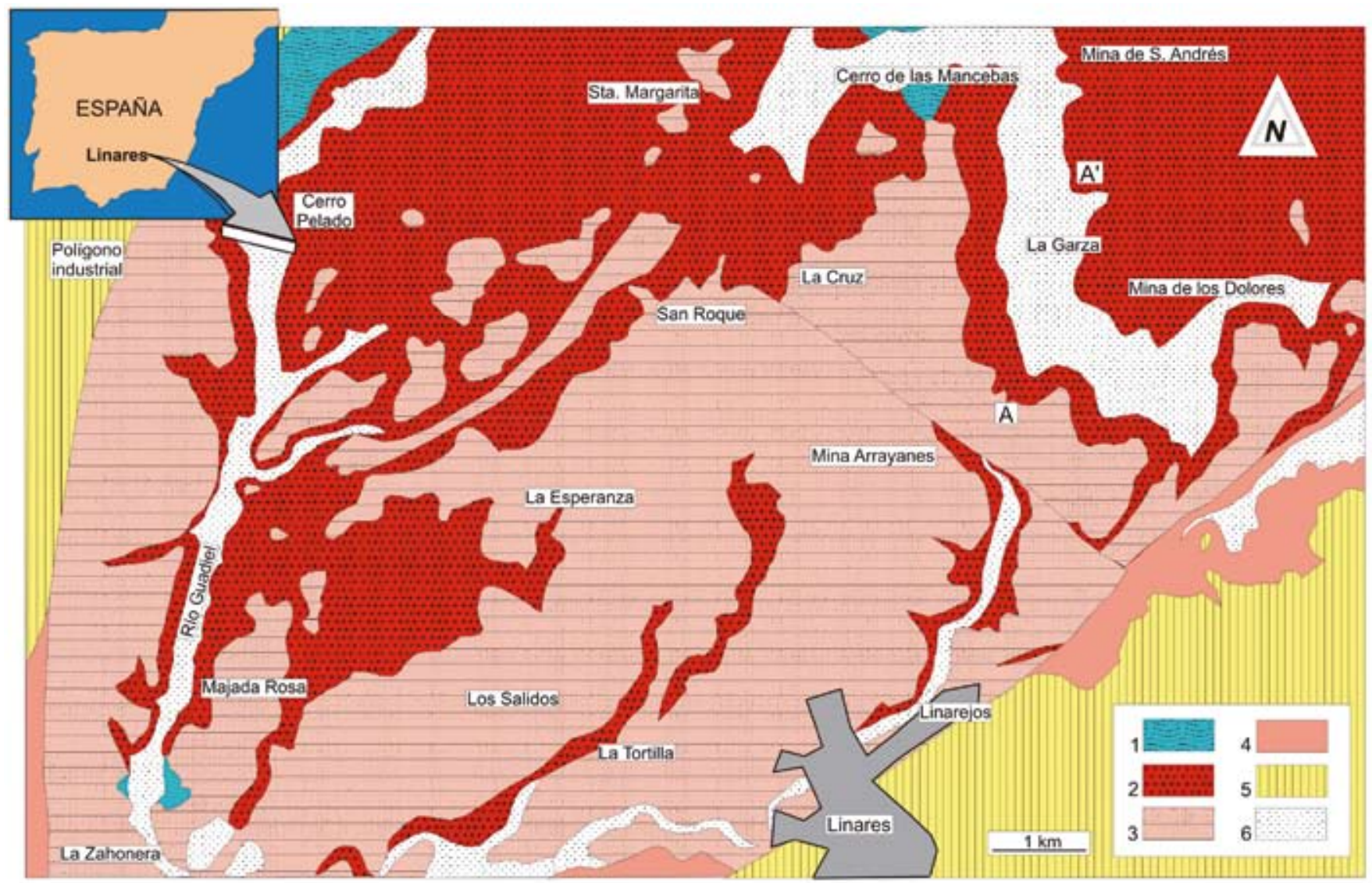

A

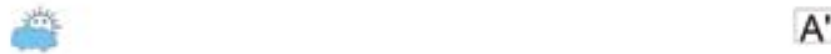

$A^{\prime}$

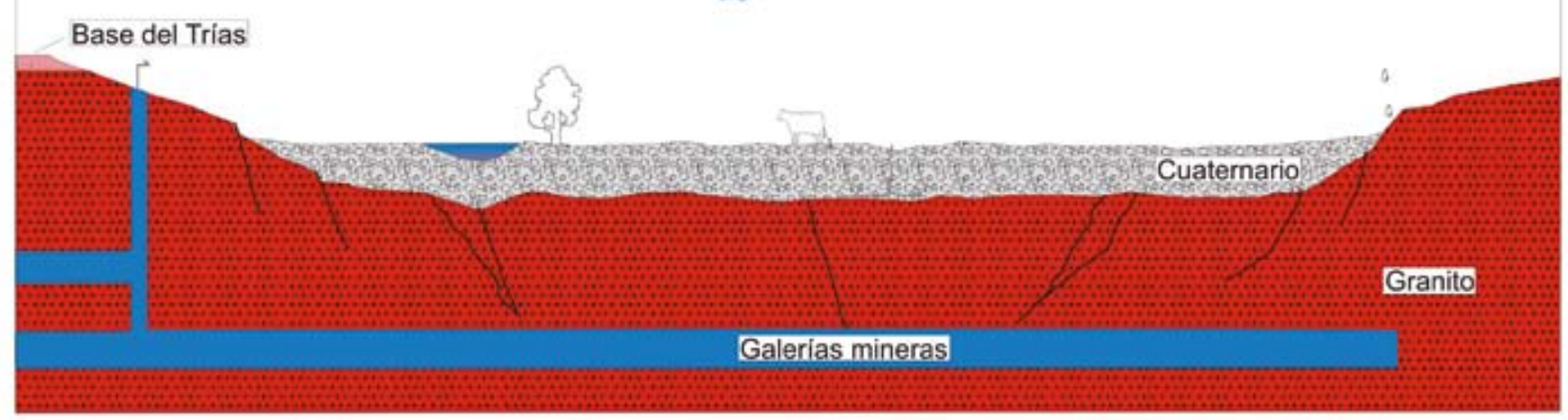

Fig. 4. Geological map of the southern area Linares - Cero Pelado (after Dueñas et al., 2000a). 1 - phyllites, 2 - granite, 3 - sandstone, 4 - clays, 5 - Triassic sediments, 6 - alluvial deposits • Mapa geologiczna obszaru południowego Linares-Cero Pelado (wg Dueñas $e t$ al., 2000a). 1 - fyllity, 2 - granit, 3 - piaskowce, 4 - gliny, 5 - osady triasu, 6 - osady aluwialne

veins of quartz and gossan interspersed with nodules of galena. Carbonates of lead, copper pyrites and carbonates and oxides of copper are also found in considerable quantities on the backs of some of the lodes, but this almost invariably disappear in depth, giving place to pure galena, and it is by no means uncommon to find the galena become a carbonate or sulphate on its leaving the granite and entering the sandstone capping. Sulphate of barites is found in considerable quantities in some of the lodes, and although not an invariable accompaniment of a rich lode, is seldom found in any quantity in a pure one. Mundic is very rare in the granite, but very common in the slate; and marked difference in this respect is observable in the ores raised from the two strata (Thomas, op. cit.).

\section{The Heritage of the Industrial and Mining activity}

The mining and smelting activities around Linares-La Carolina during the Industrial period resulted in a great variety of different buildings that changed the appearance of the region and left their mark in towns and villages; they created a distinctive landscape. The ore dressing floors, significant features in themselves, gave rise to huge waste accumulations, tailings and dams, and deeply marked the landscape. The removal of trees and bushes for fuel provoked frequent conflicts in addition to those arising from the contamination. Life in the cities and villages, and indeed the entire social structure of the region changed quickly as it 


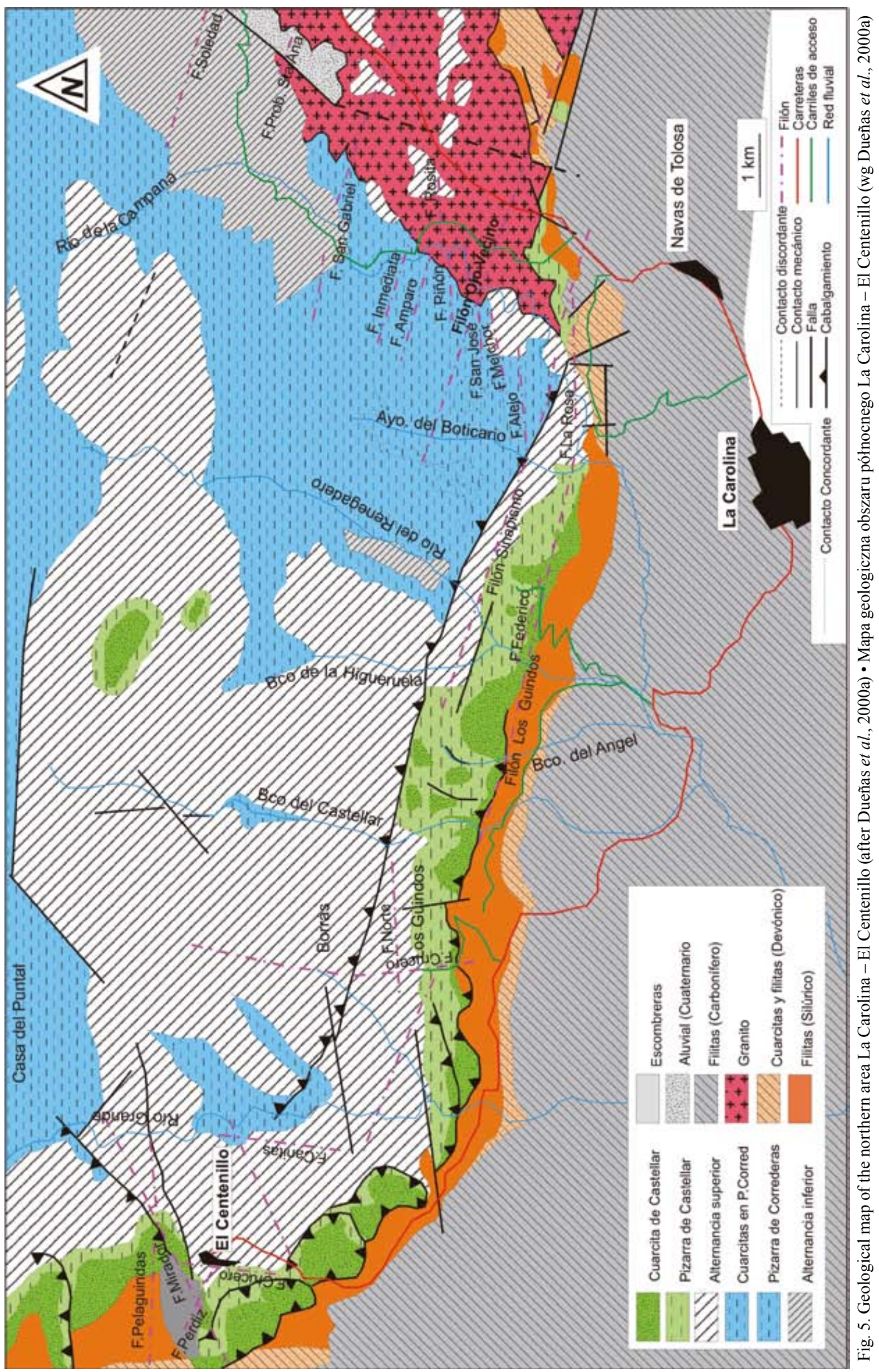




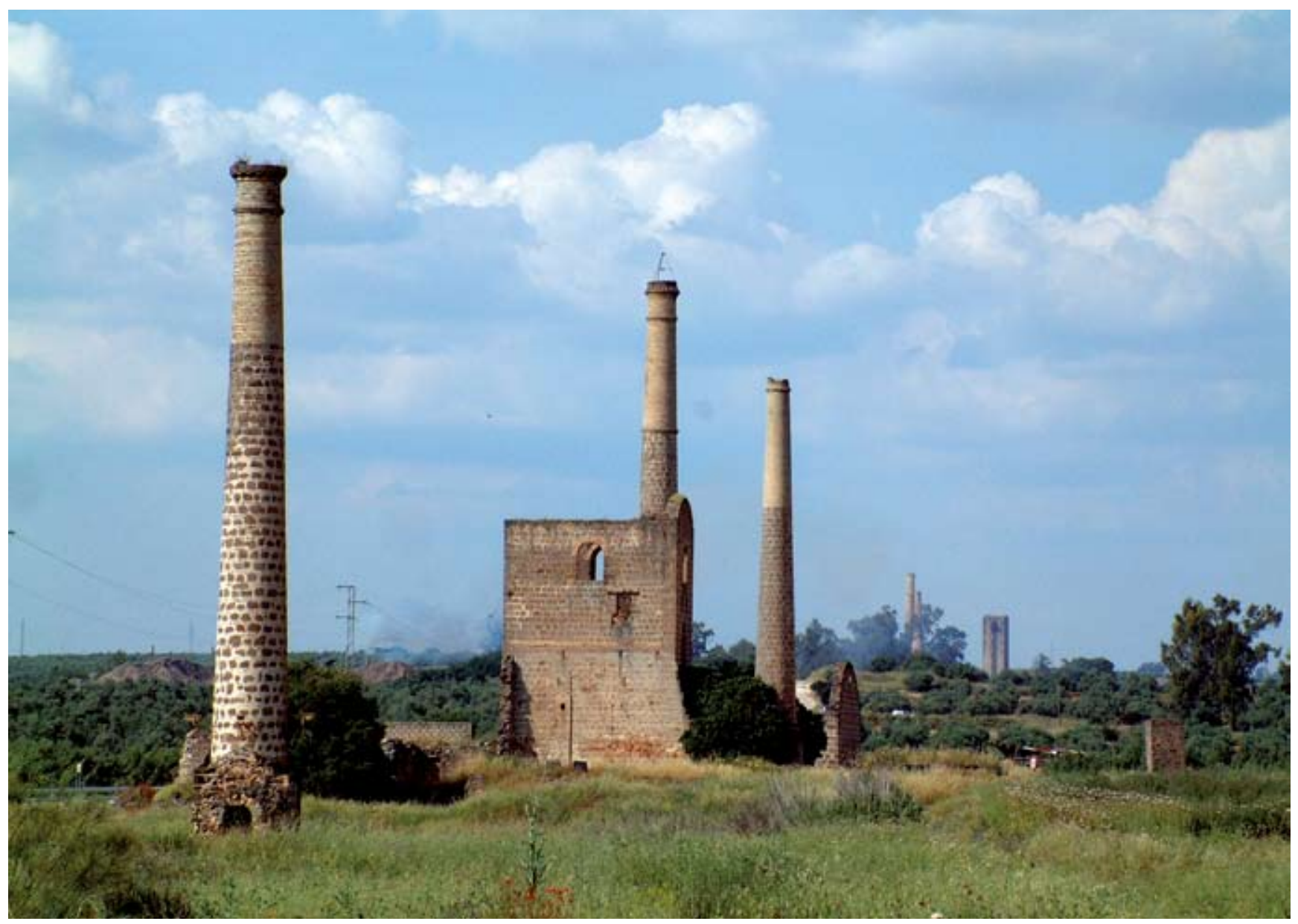

Fig. 6. View of La Tortilla's mine • Widok na kopalnię La Tortilla

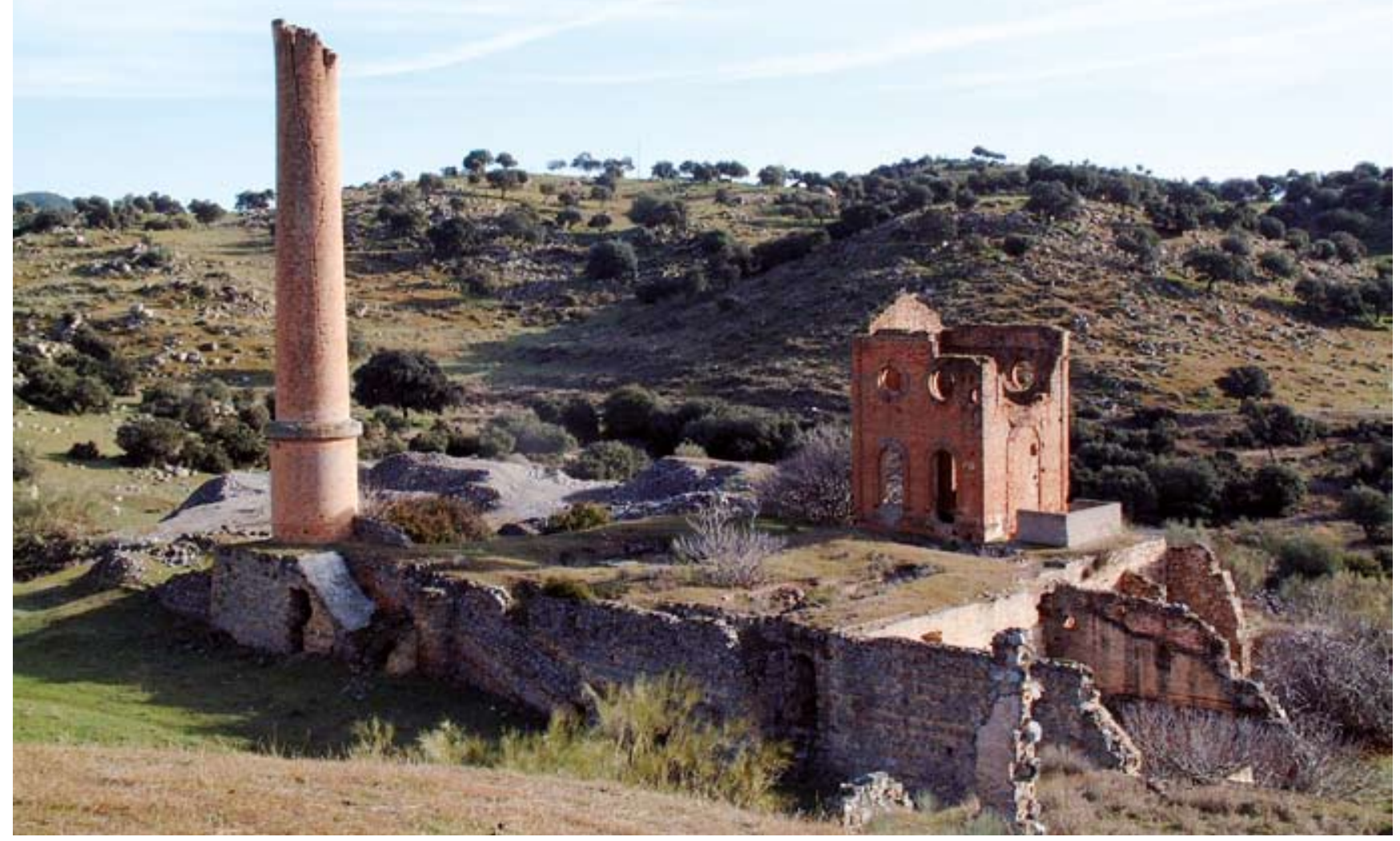

Fig. 7. French style “Bull” Engine House in San Andrés shaft (Guarromán) • Siłownia typu „Bull” we francuskim stylu nad szybem San Andrés (Guarromán) 


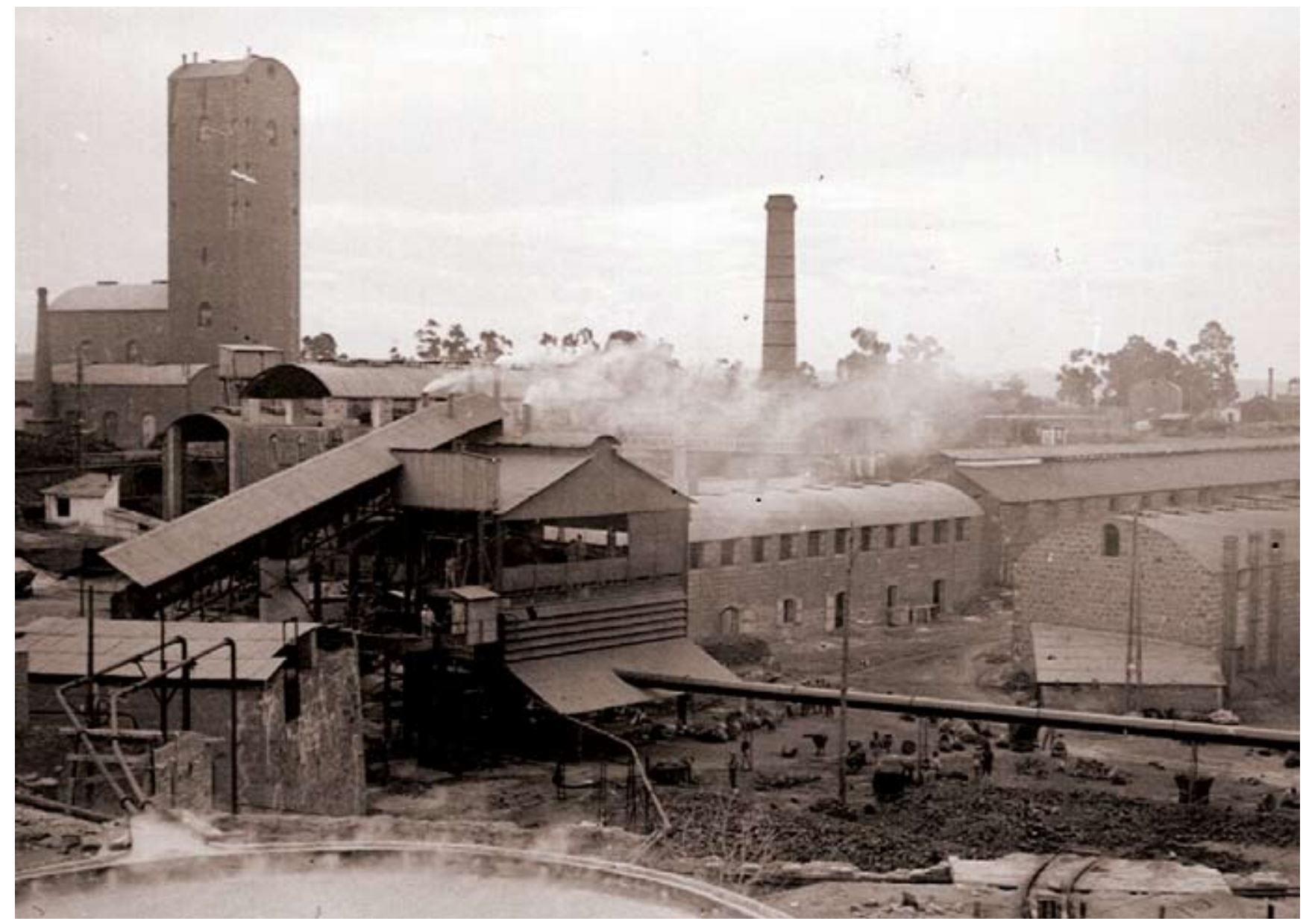

Fig. 8. General view of La Tortilla Foundry at the beginning of the $20^{\text {th }}$ Century $\bullet$ Widok ogólny huty La Tortilla z początku XX wieku

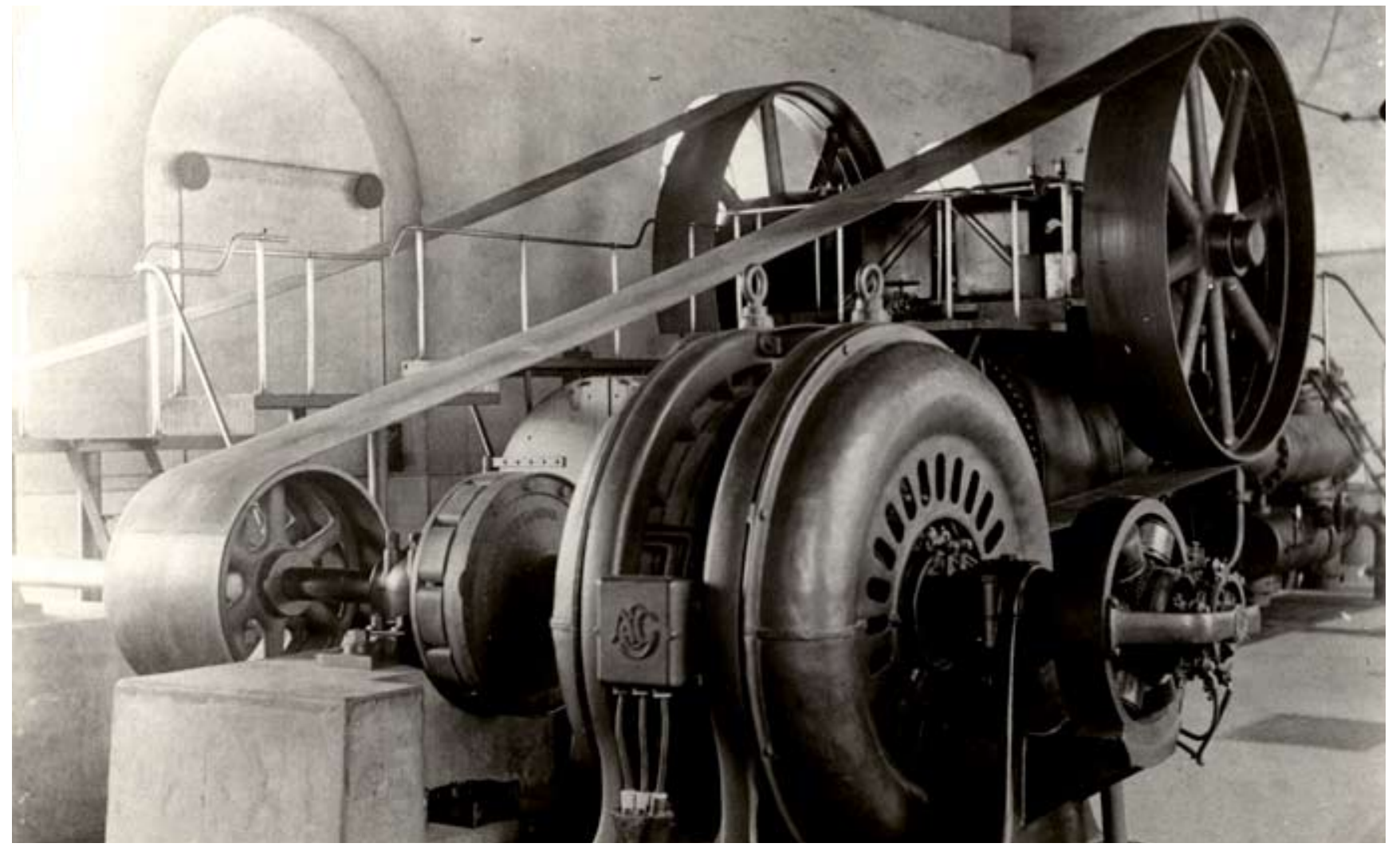

Fig. 9. Electric generator at the Electrical Central of La Manzana (La Carolina) • Generator w centrum energetycznym kopalni La Manzana (La Carolina) 


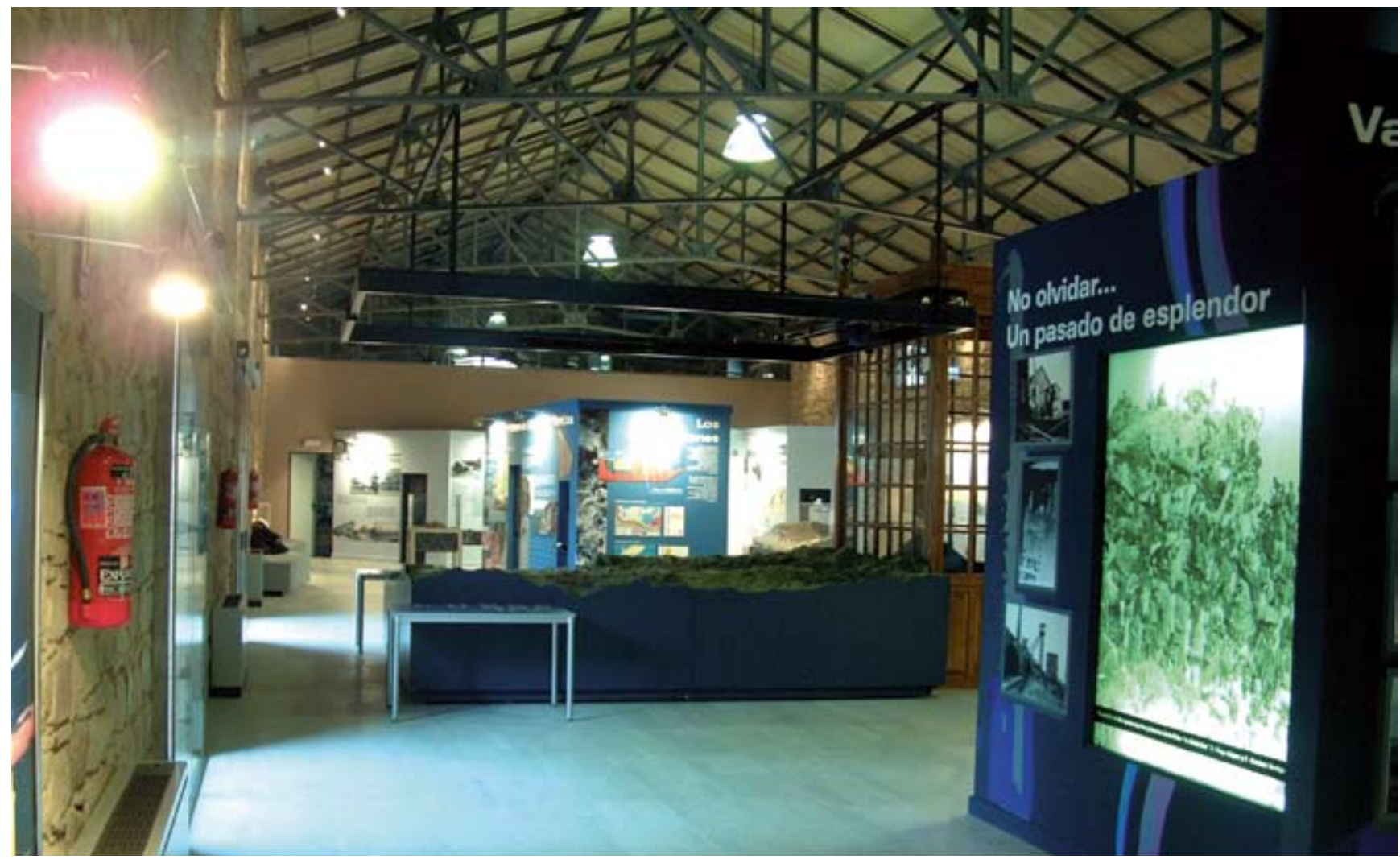

Fig. 10. Inside view of the Mining Landscape Interpretation Centre (Linares) • Wnętrze Centrum Interpretacyjnego Krajobrazu Górniczego (Linares)

adapted to the newly industrialized society. This resulted in the emergence of a new social order, particularly the rise of a new middle class comprising technicians and specialized workers from other areas and countries.

The first Cornish pumping engine was installed in Pozo Ancho Mine in 1849. It proved to be such a success that a great proportion of the area's mines were equipped with these Leviathans of the industrial world. (Mesa y Álvarez de, 1889-1890) There are still a great number of Cornish pumping Engine Houses in the district. We have catalogued 32 of these buildings. Their robustness has allowed them to continue to stand out as reference points in the landscape and as symbols of industrial architecture. (Brown, 1997). The Linares-La Carolina district has probably one of the largest concentrations of pumping engine houses in the world (Fig. 6). An extensive network of paths and roads connect the remains throughout the area and across the territory of eight municipalities.

Boiler houses were less sturdy than the pumping engine houses and there are fewer preserved examples. One exception is the house of the Sopwith Company, such as that at Pozo Santa Annie in La Tortilla Mines. In other cases, as in the house for three boilers in Pozo San Andres, only the stone foundations for the boilers remain. Some 70 remains of this type of building have been catalogued but only about 12 are in good condition (Barton, 1989).

At least three direct action engines ("Bull Engines") were installed in the district. One example was built with red bricks and round windows over a set of underground tunnels and rooms. The French-style house of San Andres is one of only three of "Bull" type that we think still exist in the world (Fig. 7). It is very well integrated into a landscape that is also of great ecological value (Brown, 1997).

A prominent example of winding technology is the iron headgear of Mina Antonita, built in the Penryn Foundry that worked in Cornwall between 1853 and 1887. In 1883, there were 88 winding engines installed. There have been catalogued about 70 winding engine houses, usually well preserved, 17 iron headgears and 17 stone headgears, all them

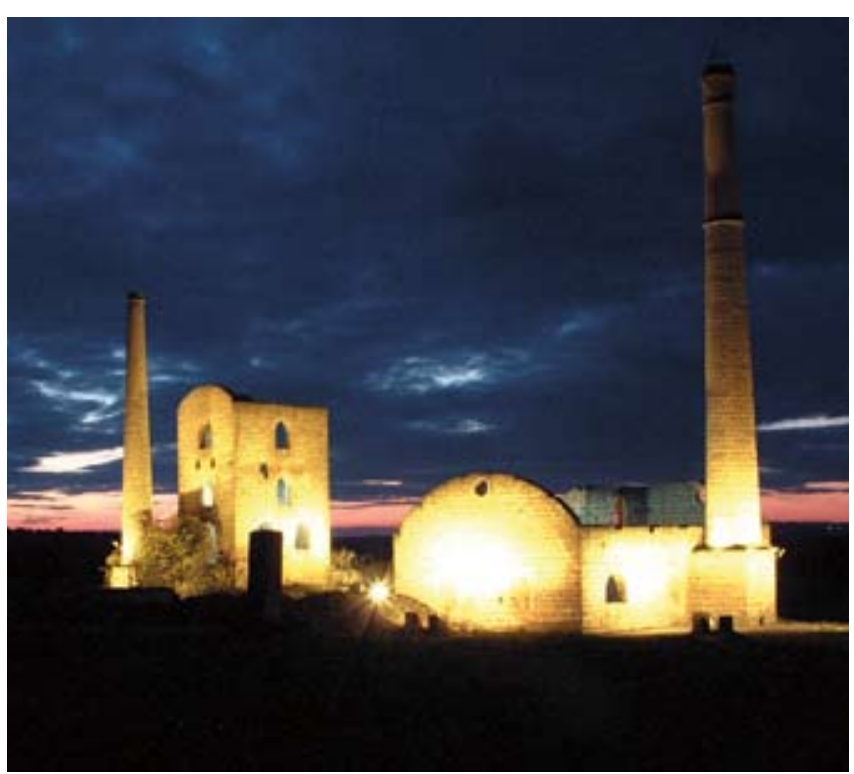

Fig. 11. Lighting buildings at San Federico shaft (Linares) • Oświetlone budynki szybu San Federico (Linares) 
very well preserved. There is no other place in the world known with similar number of these and, thus, it is considered as a defining element of Spanish mining heritage.

There is another excellent example of a beam winding engine house in Pozo Briones close La Esmeralda Mine (Anonimo. 1877). It is very similar to that at Levant Mine, in Cornwall (Rowe, 1998). A 22" engine was installed in Pozo Briones - the first of the steam era in the area .

In the dressing works, the ore was crushed and the galena separated from the waste before transport to the smelting works (Henry Davies, 1894). Six important foundries (La Cruz, Arroyo Hidalgo, La Esperanza, La Tortilla, La Fortuna and San Luis) were working at the same time in Linares and three more in La Carolina. In these, the galena was smelted to give metallic lead (Anonimo, 1877). La Tortilla Foundry, founded by Thomas Sopwith in 1874, became in 1885 the most modem and complete in Europe (Fig. 8). La Cruz Foundry was created in 1830 by the Marquis of Remisa and, later, was bought by the Neufville family of Paris. It was the last foundry to be closed in the district in 1986 and remains well preserved (Guía de Linares y su provincia, Jaén, 1880., 1993). Currently, there are four shot towers preserved in good condition, two in Linares and two in La Carolina.

Steam power was gradually replaced by electricity (Fig. 9). The power stations generated electricity from water or from steam engines. One of the most important power stations in Linares was that of the Mengemor Company. There was also a local company known as "Linarense de Electricidad". The Central Hydroelectric Power Station of El Arquillo was opened in 1921 on the Guadalimar river (Companía Sevilana de Electricidad., 1994). Apart from this supplemented waterpowered generators with steam turbines, at several mines such as El Guindo, steam-powered generators were installed (Molina Vega, 1987).

\section{The Arrayanes Project - current activities}

The Arrayanes Project was born in 1991 when a group of people from different professional fields was formed to preserve the mining and industrial heritage of the district and to ensure that its importance was recognized. At this point, all mining was about to cease. The group had the aim of preventing the despoliation and dilapidation of the remains. Since then, the group (the Colectivo) has produced several publications and held exhibitions, talks, conferences and other activities to publicize the region. The Colectivo has attended national and international conferences and as a result, the value of our mining heritage has been recognized. The Colectivo is founder member of the Andalucian Heritage Defense and Study Association (ADEPTA) as well as of The International Committee for the Conservation of the Industrial Heritage (TICCIH). It participates as a partner in the MINET European project (European Mining Heritage Network) and now is a member of the European Mining Heritage Network Europamines.

A prime objective of the Colectivo was the legal protection of the heritage. This process started in 1998, when the Re-

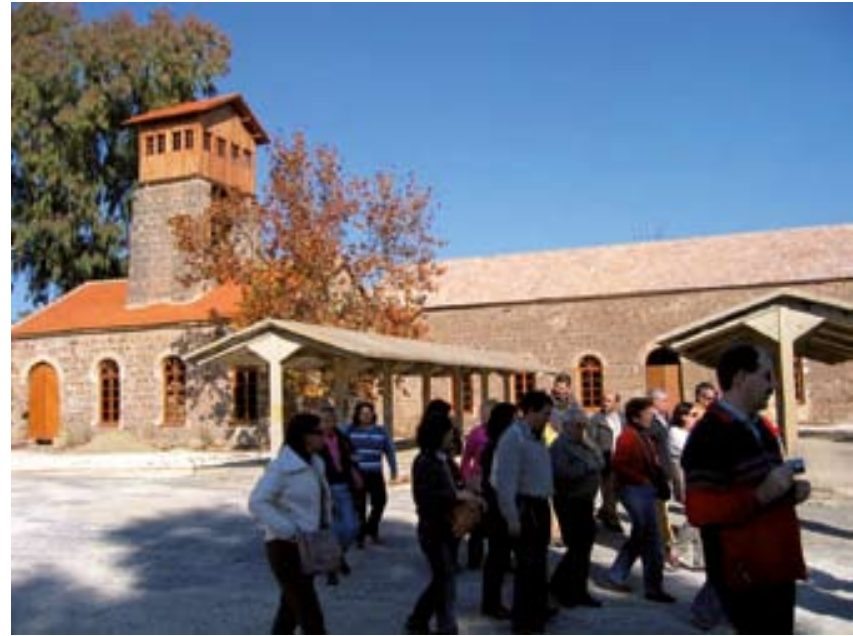

Fig. 12. Visitors at La Cruz Foundry (Linares) • Turyści na terenie huty La Cruz (Linares)

gional Culture Authority awarded the area B.I.C. (Cultural Good) status. The Department of Culture entrusted to the Colectivo the work of cataloging the mining sites of the district to be inscribed as part of the Andalusian Historic Heritage. Our association worked on this for more than six years and the first list, with 65 sites, was officially published in January 2004. The protection was completed with the inclusion of a further 60 mining sites, officially published in May 2008.

The Mining Landscape Interpretation Centre is located in a stone built warehouse in Madrid Railway Station and is the initial information point for visitors wishing to understand the importance and value of our heritage. The exhibition inside the centre has been designed to be as stimulating as possible as it aims to encourage tourists to visit the real museum: the area itself (Fig. 10).

The centerpiece is a 12 meters square model of the mining landscape with which visitors are able to interact by means of lasers that activate screens displaying various elements of the district's rich heritage. This model shows a series of walking routes inviting people to visit and explore the real museum. The halls contain exhibitions, models and artifacts housed in showcases. In addition to displays that are clear and attractive, there are several screens displaying more exhaustive and specialized information.

People visiting the Linares-La Carolina district can use a series of sign-posted paths and roads receiving, as they do so, information about the most important remains on each itinerary. Six short way-marked paths covering 58 kilometers near the town of Linares make it possible to visit the mining landscape and 23 significant mining sites. An interpretation panel giving information about the history and other relevant elements is located at each of those sites. In the near future, the network of paths will be enlarged to include all catalogued sites in the district. This network is integrated into the European Paths Network.

The flood-lighting project is intended to highlight the symbolic value of the mining remains. It began with the lighting of remains located beside roads leading to Linares (Fig. 11). Currently, the "Minas de Los Lores", an iron headgear and the Mine Las Angustias, on the roads from Bailén 


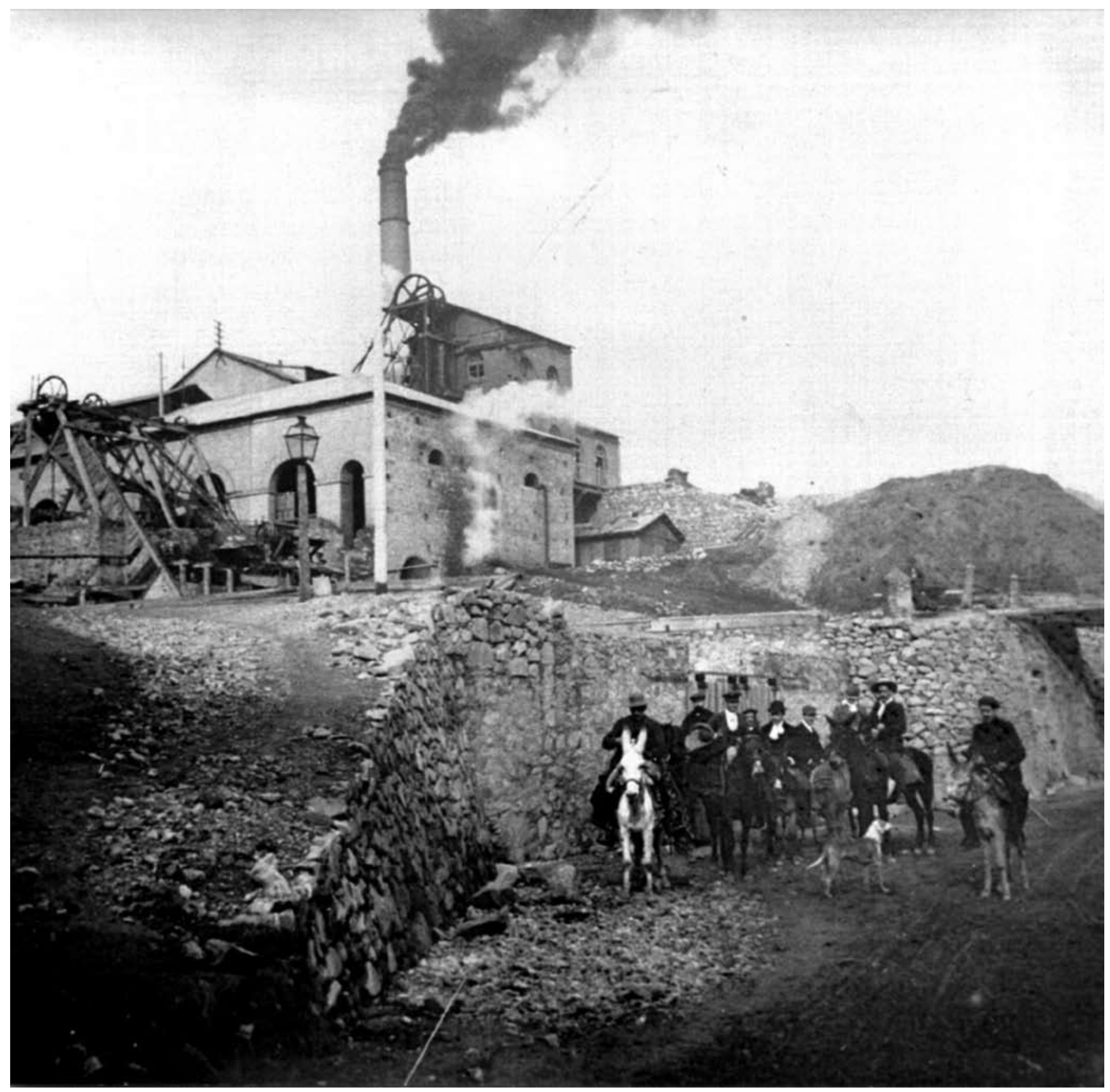

Fig. 13. Mining installations at San Andrés in the first 20th Century • Urządzenia górnicze w San Andrés na początku XX wieku

and Bańos de la Encina, are floodlit. In the near future, the remains of Pozo Ancho Mine on the road from Guarroman will be floodlit also.

The Metallurgy Interpretation Centre, a key part of the main project, is sited in the old La Cruz Foundry which worked from 1830 (Fig. 12). The first stage of the recovery work has made visits to the shot manufacturing area possible. In the near future, the smelting process will be reproduced in two warehouses that date from the early $20^{\text {th }}$ Century.

\section{Future Projects}

The project must be able to turn the mining heritage of the district into a real resource for social regeneration and an attraction for visitors looking for cultural- and eco- tourism and research. The population of the area must recover a pride in their heritage which was lost when the mines closed. All actions must be coherent and must be integrated with initiatives of the local, provincial and regional authorities, as well as with those of private and other institutions so that all can contribute to the overall objective. Consequently, a number of further initiatives are planned.

A long term aim of the Colectivo is to get the Mining Landscape of the the Linares-La Carolina district designated as a UNESCO World Heritage Site. This will ensure that future generations will benefit from an understanding of how mining, mankind's oldest industry, has contributed to the development of society - socially, culturally, economically and technologically - since the dawn of human habitation in the Stone Age.

The aim of the Mining Interpretative Centre will be to show a typical mine. It will be located in the La Tortilla Mines 


\section{ACCESS ADIT TO LA MANZANA SHAFT PLAN OF EXPLANATORY AND ATMOSPHERE CONTENTS}

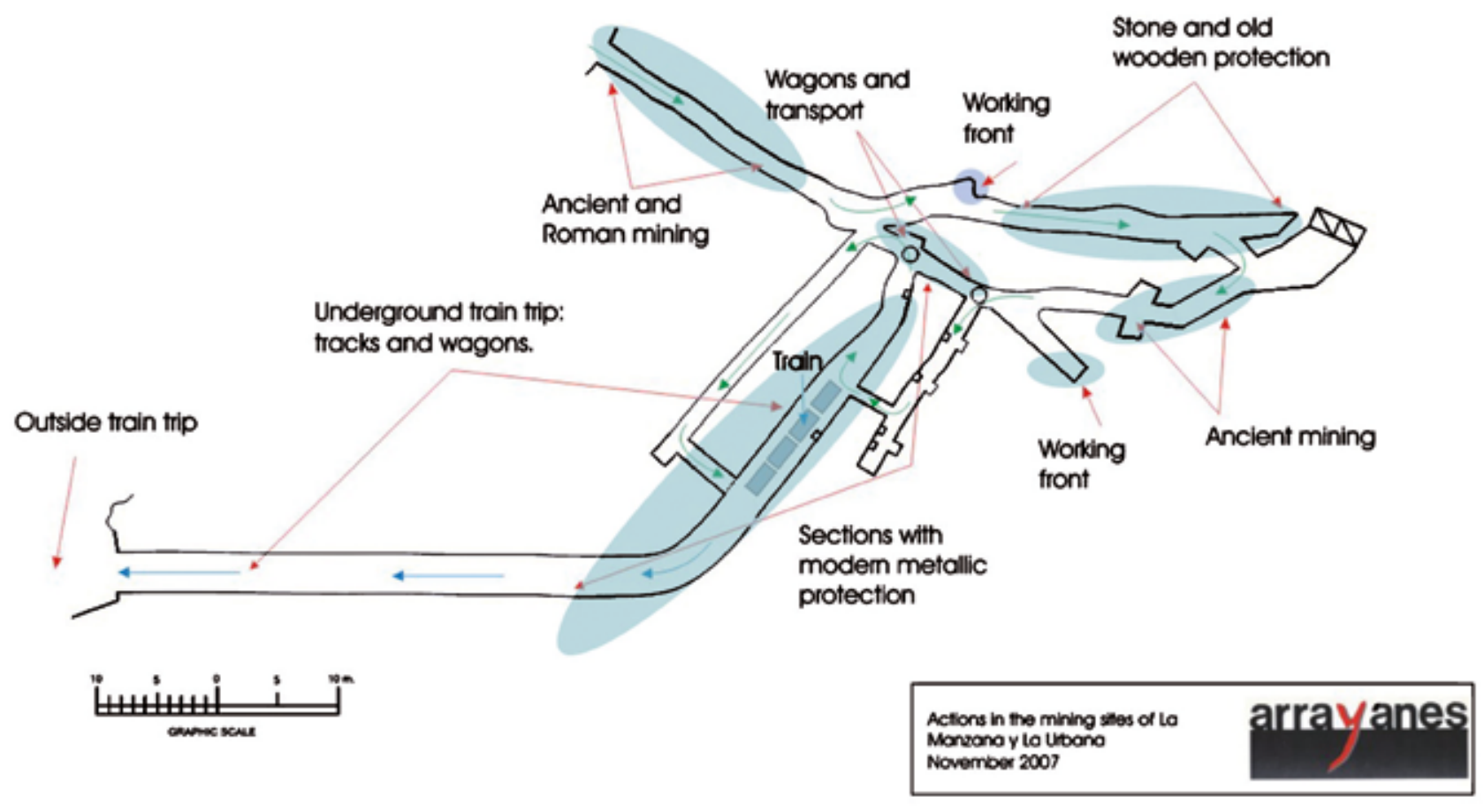

Fig. 14. Sketch of the project for the access adit of La Manzana (La Carolina) • Szkic projektu dostępu do sztolni kopalni La Manzana (La Carolina)

which are now in public ownership. Contributions from the Culture Ministry, the Regional Architecture Department and the Town Council will enable the preservation and restoration of the surviving buildings. The centre will show the surface features of the mine and will demonstrate the use of Cornish steam technology for pumping and winding as used in the region at the end of the 19th Century.

This project is based on the unique surviving "Bull" engine house that was built at this mine at the beginning of the $20^{\text {th }}$ Century (Fig. 13). The project was approved by the tourist authorities five years ago but implementation was postponed by the Guarroman Town Council. The museum will include a visitor reception area, access to tunnels below the engine house and the "Bull" engine house itself. There will be a reconstruction of manual ore dressing as well as recreational paths and viewing points.

As a consequence of increased visits to the area, it is necessary to improve safety conditions near the mines by capping open shafts and signposting and fencing areas of collapse along the lines of old workings. It will be necessary to make an inventory of dangerous areas and to deal with them appropriately. Our association has requested funds from the employment and technological development authorities to carry out this work but it will be necessary to extend its scope. The Colectivo has just completed a campaign to emphasize the need of security involving several visits to the mine sites and publication of information about security in the mining areas.

The Linares-Los Salidos Mining Railway, which runs for about 12 kilometers, covers the mining fields in the northern area near Linares which belonged to the most important companies. Its restoration will allow easy access across a beautiful and ecologically-rich landscape (Mesa y Álvarez de, 1889-1890).

It would be a very attractive proposition to demonstrate the underground workings. However, the absence of horizontal adits in the mines makes their adaptation for tourist visits very difficult. Thus, it will be necessary to build an artificial mine, a Show Mine, to be located in La Tortilla Mines close the interpretation centre and adapted to simulate underground workings. Research work has started recently and it is aimed to complete construction in 2010 (Fig. 14). In addition, it is planned to adapt one underground level of La Manzana Mine, in La Carolina, for visits showing how the undergrounds workings were in different periods.

Several archaeological investigations are currently underway in the area. They have confirmed the antiquity of mining and smelting in the region (Contreras Cortés, et al., 1997). These could be included as part of the tourist experience. The reconstruction of an Iberian-Roman settlement, including a small village and a mine to illustrate how this area developed at the start of its mining history, could be a key element. This 
project will comprise the ancient mining routes and revaluation of an Iberian-Roman settlement.

The landscape of the Linares-La Carolina mining district should be a real museum that people would wish to visit. There is a need to preserve and interpret both artifacts and a way of life. The Arrayanes Project has been, and must be in the future, a partnership between the local people and their heritage. In the longer term, a number of additional projects will contribute to achieving this:

- Cataloguing of machinery, tools and equipment.

- Document Centre archiving written documents, photographs, plans, maps, etc.

- The El Centenillo mines and village - restoration of a mining settlement

- Oral history - testimonies from those who experienced the reality of mining.

- Long distance way-marked paths and roads connecting the north and south of the area and linking with the shorter paths in each area.
- Preservation of Roman remains in Palazuelos and La Fernandina.

- Publication of books, articles and leaflets to raise awareness

The future of the project can be summarized as follows:

- To promote the cultural heritage of the area.

- To ensure this heritage is understood and valued.

- To promote the reuse of the mine remains.

- To provide the necessary management structures to meet these aims.

- To maintain the independence of the Colectivo.

- To establish good relationships with other areas and countries with the same heritage.

- To transform the heritage into a resource for sustainable development.

\section{Acknowledgements}

Authors thanks Dr. Pádhraig S. Kennan for his kind help in English.

\section{Streszczenie \\ Kulturowy krajobraz rejonu górniczego Linares-La Carolina (Hiszpania)}

\section{Antonio Angel Peréz Sánchez, Marek W. Lorenc}

\section{Rejon górniczy Linares-La Carolina}

Rejon górniczy Linares-La Carolina, położony na północy prowincji Jaén w Andaluzji, rozciąga się na odległość około $40 \mathrm{~km}$ na południe od Despeñaperros w Sierra Morena oraz na odcinku około $30 \mathrm{~km}$ ze wschodu na zachód (Fig. 1).

Jest to dziedzictwo o międzynarodowym znaczeniu historycznym, technologicznym, kulturowym i ekonomicznym, o szczególnym nagromadzeniu zabytków. Niektóre z nich, niespotykane nigdzie indziej, przedstawiają pozostałości intensywnej „Rewolucji Przemysłowej”. Cztery tysiące lat historii górnictwa ukształtowało unikalny krajobraz ukazujący jak ludzkość była związana ze swoim środowiskiem od czasu epoki Brązu, kiedy to ludność rolnicza nadciągająca z południowego-zachodu, poszukiwała miedzi i wznosiła swoje osady wzdłuż brzegów rzek płynących z Sierra Morena (Contreras, 2000). Badana aktualnie przez archeologów z Uniwersytetu w Granadzie osada Peńalosa była punktem ogniskującym systematyczną kolonizację rejonu Rumblar (Fig. 2).

Później, Rzymianie i Kartagińczycy, stworzyli wiele kopalń w okolicach Linares (np. Arrayanes i La Cruz), a także w Sierra Morena (El Centenillo i Salas de Galiarda), eksploatujących bogate złoża miedzi i ołowiu. Pozostałości obronnych fortyfikacji ewidentnie dowodzą wielkiego znaczenia działalności górniczej i metalurgicznej.

W okresie Rzymskim, stolicą rejonu górniczego było miasto Castulo, położone niedaleko Linares. Dokumenty datowane od $1563 \mathrm{r}$. odnoszące się do koncesji w tym rejonie, potwierdzają ciągłą eksploatację tutejszych złóż także w Średniowieczu i w okresie dominacji muzułmańskiej.
W roku 1749 hiszpańskie królestwo zainteresowało się tym obszarem wybierając kopalnie Arrayanes jako wiodące w skali kraju.

\section{Rys geologiczny rejonu górniczego}

Rejon ten podzielony jest na dwa obszary o odmiennej budowie geologicznej i morfologicznej (Fig. 3). Obszar południowo-wschodni obejmuje krajobraz wiejski i podnóże Sierra Morena okolice Bailén, Linares, Vilches i Guarromán (Fig. 4). Bogata rzeźba terenu, będąca efektem intensywnej erozji, charakteryzuje się bogactwem wzgórz i dolin. Skałą rudonośną $w$ tym obszarze jest bogaty w skaleń i ubogi w mikę granit. Przykrywa go kwarcowy piaskowiec, miejscami zalegający na pośredniej warstwie gliny. Rudne żyły wypełniają szczeliny w granicie, przechodzące wyżej także w obręb piaskowca. Geologiczna ewolucja tego obszaru przebiegała w trzech etapach. Po pierwszym etapie naprężeń ekstensywnych i drugim - kompresyjnych, generujących wiele stref uskokowych, etap trzeci, w którym szczeliny otwierały się i formowały się rudne żyły, był związany z wielkoskalową aktywnością magmową, generującą system późniejszych utworów hydrotermalnych, obfitujących w mineralizację rudną.

Obszar północno-zachodni obejmuje okolice Baños de la Encina, Carboneros, La Carolina i Santa Elena (Fig. 5). Występują tu paleozoiczne skały metamorficzne stopnia średniego i niskiego, formujące trzy grupy litologiczne. Najniższą stanowią kwarcyty i fyllity, środkową - łupki ilaste, znane jako tzw. „łupki śliskie”, a najwyższą - wapienie i kolejne łupki ilaste. Łupki ilaste, na kontakcie z granitem przeobrażone są w skałę przypominającą bardzo drobnokrystaliczny granit. Bogate w galenę żyły przecinają zarówno granit jak i wyżej ległe łupki.

Kruszconośne żyły, zbudowane z hydrotermalnie zmienionych partii granitu, przecinanego przez żyły kwarcowe $\mathrm{z}$ nodulami galeny $\mathrm{w}$ całym regionie zapadają ku NE pod kątem od $40^{\circ}$ do $70^{\circ}$. Spotyka się w nich także znaczne ilości 
węglanu ołowiu, żelaza i miedzi, a także siarczki żelaza i miedzi. Wraz z głębokością wzrasta zawartość czystej galeny, która w obrębie piaskowca ustępuje miejsce ww. węglanom. W niektórych żyłach występuje też baryt.

\section{Pozostałości działalności górniczej \\ i hutniczej}

Działalność górnicza i hutnicza w okolicach Linares w okresie intensywnego rozwoju przemysłowego zaowocowała powstaniem dużej różnorodności budowli, które zmieniły wygląd całego regionu, pozostawiając swoje niezatarte znamię w miastach i wsiach, tworząc też charakterystyczny krajobraz. Zakłady przetwórcze rudy, bardzo charakterystyczne same w sobie, dały też początek gromadzeniu się wielkiej ilości hałd i odpadów poflotacyjnych, znacznie zmieniających krajobraz. Masowy wyrąb drzew i krzewów na opał prowokował liczne lokalne konflikty społeczne. Życie ludzi w miastach i wsiach znacznie zmieniało się, prędko formując nowe społeczeństwo przemysłowe.

Pierwszy silnik maszyny odwadniającej, pochodzący z Kornwalii, został zainstalowany w szybie Pozo Rancho w 1849 r. Niebawem znaczna część kopalni na tym terenie została wyposażona w podobnego typu „olbrzymy” świata przemysłowego. Do chwili obecnej na tym obszarze istnieje wiele maszynowni typu kornwalijskiego, zarówno pompowych jak i wyciągowych. Ich mocna konstrukcja pozwoliła przetrwać jako punkty odniesienia w krajobrazie i jako symbole architektury przemysłowej. Rejon Linares-La Carolina reprezentuje przypuszczalnie największe zagęszczenie maszynowni tego rodzaju na świecie (Fig. 6).

Budynki kotłowni były mniej wytrzymałe na destrukcję niż maszynownie i do chwili obecnej zachowało się ich niewiele. Skatalogowano 70 pozostałości po tego typu budynkach, ale tylko $12 \mathrm{z}$ nich jest $\mathrm{w}$ dobrym stanie.

Silniki typu „Bull Engine” zainstalowano w tym rejonie tylko trzy. Jeden z nich funkcjonował w budynku wzniesionym z cegły i utrzymanym w francuskim stylu w kopalni San Andres. Jest to jeden z tylko trzech zachowanych takich budynków na świecie (Fig. 7.).

Najlepszym przykładem zabytku technologii wyciągowej jest metalowa wieża w kopalni Antońita, która funkcjonowała w latach 1853-1887. W 1883 r. w kopalniach zainstalowano 88 parowych maszyn wyciągowych. Obecnie skatalogowano 70 takich maszynowni, w większości dobrze zachowanych. Istnieje możliwość znalezienia jeszcze 17 stalowych wież, a 17 już skatalogowano.

Przed transportem do huty, w zakładach przeróbczych ruda była kruszona, a galena separowana od płonnej skały. Równocześnie funkcjonowało w Linares sześć hut (La Cruz, Arroyo Hidalgo, La Esperanza, La Tortilla, La Fortuna i San Luis) oraz dwie w La Carolina. W nich z galeny wytapiano metaliczny ołów. Huta La Tortilla wzniesiona w 1874 r. już po roku stała się najnowocześniejszą hutą w Europie (Fig. 8). Obecnie, w dobrym stanie zachowane są tylko cztery wieże śrutowe: dwie w Linares i dwie w La Carolina.

$\mathrm{Z}$ czasem napęd parowy został zastąpiony elektrycznym (Fig. 9). Nowej generacji silniki zasilane były energia wytwarzaną przez elektrownie wodne względnie napędzane wciąż jeszcze silnikami parowymi. Centralą elektrownię wodną El Arquillo uruchomiono na rzece Guadalimar dopiero w $1921 \mathrm{r}$.

\section{Dzialalność grupy Colectivo Proyecto Arrayanes}

Projekt Arrayanes powstał w 1991 r., gdy grupa ludzi różnej profesji zawiązała się, aby ratować i zachować dziedzictwo górnicze i przemysłowe regionu. Od tego czasu zespół o nazwie Colectivo Arrayanes wydał wiele publikacji, zorganizował wiele wystaw i konferencji dla społeczności tego regionu. Zorganizował też nowoczesne Centrum Interpretacyjne Krajobrazu Górniczego, adaptując na ten cel budynek magazynowy nieczynnej stacji kolejowej. Wewnątrz znajduje się stała, bogata ekspozycja muzealna historii górnictwa i hutnictwa, model rejonu górniczego o powierzchni $12 \mathrm{~m}^{2}$ $z$ elektronicznym sterowaniem $i$ audiowizualną prezentacją, a także sala konferencyjna (Fig. 10).

Ciekawą inicjatywą Colectivo była realizacja projektu, mającego na celu iluminację zabytków górniczych na terenie i w pobliżu miasta Linares (Fig. 11). Oświetlone są w ten sposób m.in. zabudowania kopalni Los Lores na peryferiach miasta oraz wieża wyciągowa dawnej kopalni Las Angustia w centrum Linares. Planuje się też wykonać iluminację obiektów kopalni Pozo Ancho przy drodze z Guarroman.

Stworzenie Centrum Interpretacyjnego Metalurgii jest kolejnym projektem. Będzie się ono mieścić na terenie dawnej huty La Cruz, której zabudowania są właśnie w trakcie renowacji i adaptacji (Fig. 12). Jedną z atrakcji będzie rekonstrukcja wieży śrutowej i prezentacja procesu produkcji śrutu.

Stworzenie Centrum Interpretacyjnego Górnictwa na terenie dawnej kopalni La Tortilla jest kolejnym projektem do przyszłej realizacji. Między innymi będzie tu demonstrowane wykorzystanie kornwalijskiej technologii parowej do napędu maszyn wyciągowych i odwadniania kopalń tak, jak to wyglądało w XIX wieku. Projekt ten bazuje też na jedynym zachowanym budynku silnika typu „Bull” zainstalowanego w tej kopalni na początku XX wieku (Fig. 13).

Wobec braku zachowanych i zabezpieczonych podziemnych wyrobisk, planowane jest stworzenie na terenie kopalni La Tortilla „sztucznej kopalni” i podziemnej trasy demonstracyjnej (Fig. 14). Zakończenie tych prac przewidywane jest w roku 2010. Ponadto zaadoptuje się dla celów turystycznych istniejące sztolnie kopalni La Manzana w La Carolina dla ukazania jak wyglądały podziemne wyrobiska w różnych okresach wydobywania rudy.

Cały rozległy obszar górniczy Linares-La Carolina powinien stać się otwartym muzeum, które społeczeństwo chciałoby odwiedzać. Długoterminowym projektem jest rozpoczęcie procedury zgłoszenia Krajobrazu Górniczego rejonu Linares-La Carolina na listę Stanowisk Światowego Dziedzictwa UNESCO. Planowane są też długoterminowe działania obejmujące m.in.:

- Skatalogowanie zachowanych obiektów, sprzętów, narzędzi i wyposażenia,

- Archiwizacja dokumentów, fotografii, planów, map, itp.,

- Rewitalizacja osady górniczej El Centenillo,

- Zapis przekazów słownych uzyskanych od osób, które pracowały w tutejszym górnictwie, 
- Wytyczenie szlaków i ścieżek turystycznych łączących obszar północny z południowym oraz w obrębie tych obszarów,

- Zachowanie Rzymskich pozostałości w Palazuelos i La Fernandina,

- Opublikowanie książek, artykułów i broszurek informacyjnych.

Podsumowaniem tych działań powinno być:

- Promocja kulturowego dziedzictwa tego obszaru,
- Zapewnienie zrozumienia i waloryzacji tego dziedzictwa,

- Promocja wtórnego użytkowania pozostałości górniczych,

- Zabezpieczenie odpowiedniej struktury zarządzania posiadanym dziedzictwem,

- Ustanowienie współpracy z innymi obszarami i krajami posiadającymi podobne dziedzictwo,

- Przekształcenie dziedzictwa w element zrównoważonego rozwoju regionu.

\section{References (Literatura)}

Anonimo. 1877. Estudio geológico industrial de los filones de galena de la Mesa granítica de Linares, provincia de Jaén. Linares.

Arboledas Martínez, L., 2007. Aproximación al estudio de la minería y metalurgia romana en el Alto Guadalquivir. Universidad de Granada, Granada.

Azcárate, J.E., 1977. Hoja geologica de Linares. Instituto Geológico y Minero de España. Madrid.

Barton, D.B., 1989. Cornwall's Engine Houses. Exeter.

Bennett, J. \& Vernon, R., 2002. Metal Mines of Llanengan. Yorkshire 2002. The Journal of the Mining Heritage Trust of Ireland. No. 3.

Brown, K., 1997. Exploring Cornish Mines. Truro.

Compañía Sevilana de Electricidad., 1994. Cien años de Historia. Edita: Fundación Sevillana de Electricidad. Sevilla.

Contreras Cortés, F. (Dir.), 2000., Análisis histórico de las comunidades de la Edad del Bronce del Piedemonte meridional de Sierra Morena y Depresión Linares-Bailén. Proyecto Peñalosa, Arqueología. Monografías 10, Consejería de Cultura, Sevilla.

Contreras Cortés, F.., Rodriguez Ariza, Ma.O., Cámara Serrano, J.A. \& Moreno Onorato, A., 1997. Hace 4000 anos... Vida y muerte en dos poblados de la Alta Andalucía, Junta de Andalucía, Granada.

Dueñas, J., Hidalgo, M.C. \& Rey, J., 2000a. Itinerario minero en el distrito de Linares (Jaén). International Conference "Patrimonio geológico y minero en el marco del desarollo sostenible. Linares.
Dueñas, J., Hidalgo, M.C. \& Rey, J., 2000b. Itinerario minero en el distrito de La Carolina (Jaén). International Conference "Patrimonio geológico y minero en el marco del desarollo sostenible. Linares.

Guía de Linares y su provincia, Jaén, 1880., 1993. Ed. facs. Linares: Colegio Oficial de Ingenieros Técnicos de Minas de Linares.

Henry Davies, E., 1894. Machinery for Metalliferous Mines. London.

Itinerario minero por el distrito de Linares y La Carolina., 2000. En: Patrimonio geológico y minero en el marco del desarrollo sostenible: ponencias y comunicaciones presentadas en el Congreso Internacional sobre Patrimonio Geológico y Minero en el Marco del Desarrollo Sostenible y V Sesión Cientifica de la Sociedad Espanola para la Defensa del Patrimonio Geológico y Minero, Escuela Universitaria Politécnica, Linares (Jaén), 20 a 22 de octubre de 2000. Instituto Geológico y Minero de España. Madrid.

Mesa y Álvarez P. de, 1889-1890. Memoria sobre la zona minera Linares-La Carolina. Revista Minera, Metalúrgica y de Ingeniería. Madrid.

Molina Vega, A., 1987. Minería y actividades empresariales en el distrito minero Linares-La Carolina: La Sociedad Minera "el Guindo": (18991920). Jáen : Cámara Oficial de Comercio e Industria de la Provincia de Jaén.

Rowe, C., 1998. Drawings of the Levant Whim. Journal of the Trevithick Society Vol. 25

Thomas, J. L., 1857. Notes of the Lead-Mining District of Linares. London. 